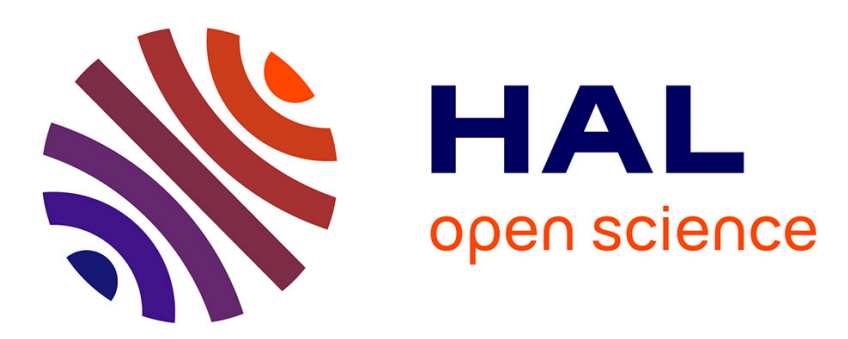

\title{
Exploring Personal Computing Devices Ownership Among University Students in Indonesia
}

\author{
Ahmad R. Pratama
}

\section{To cite this version:}

Ahmad R. Pratama. Exploring Personal Computing Devices Ownership Among University Students in Indonesia. 14th International Conference on Social Implications of Computers in Developing Countries (ICT4D), May 2017, Yogyakarta, Indonesia. pp.835-841, 10.1007/978-3-319-59111-7_70 . hal01650121

\section{HAL Id: hal-01650121 \\ https://hal.inria.fr/hal-01650121}

Submitted on 28 Nov 2017

HAL is a multi-disciplinary open access archive for the deposit and dissemination of scientific research documents, whether they are published or not. The documents may come from teaching and research institutions in France or abroad, or from public or private research centers.
L'archive ouverte pluridisciplinaire HAL, est destinée au dépôt et à la diffusion de documents scientifiques de niveau recherche, publiés ou non, émanant des établissements d'enseignement et de recherche français ou étrangers, des laboratoires publics ou privés. 


\title{
Exploring Personal Computing Devices Ownership Among University Students in Indonesia
}

\author{
Ahmad R Pratama ${ }^{1,2}$ \\ ${ }^{1}$ Department of Technology \& Society, Stony Brook University, Stony Brook, NY, US 11794 \\ ${ }^{2}$ Department of Informatics, Universitas Islam Indonesia, Sleman, DIY, Indonesia 55584 \\ ahmad.pratama@stonybrook.edu, ahmad.rafie@uii.ac.id
}

\begin{abstract}
This study investigated ownership of desktops, laptops, smartphones, and tablets using survey information on Indonesian university students. The data show that $98 \%$ of students own at least two of these personal computing devices. Laptop \& smartphone are the most common bundle to have, owned by $41 \%$ while $15 \%$ own all four of them. Applying logistic regression method to the dataset shows that student socioeconomic status has no effect on laptop and smartphone ownership but it is strongly associated with desktop and tablet ownership. Gender preference is also indicated in tablet ownership where females are more likely to own than males. Furthermore, the same logistic regression method applied to device bundle ownership shows that students with high socioeconomic status are way more likely to own all four devices while the opposite is true for laptop \& smartphone bundle ownership. The findings in this research can serve as a foundation for further research in quest of optimizing technology use to improve educational attainment, especially among Indonesian students.
\end{abstract}

Keywords: Indonesia, higher education, smartphone, tablet, laptop, desktop

\section{Introduction}

Personal computer has been around for home use since the 1970s, followed by portable computer or laptop in the 1980s. By 1990s, people started using the Internet at home and by 2000s smartphone gained its popularity, all the more so with the release of Apple iPhone and Google Android OS in 2007 and 2008 respectively. With the launch of iPad and multiple variants of Android counterpart in the 2010s, tablets were the latest addition to the lineup. The trend shows it is becoming more and more mobile oriented. It is also worth to note that many studies confirmed the assertion that device ownership is growing rapidly among university students all over the world [4, 13-14].

Meanwhile in Indonesia, the fourth most populous country in the world, the statistics of ICT adoption are promising. Internet penetration went up significantly from 15\% [9] to $51 \%$ within the past three years [12]. Indonesia has the highest growth in internet user (51\%), more than five times of the global average between 2016 to 2017 [12]. In 2014, mobile connections in Indonesia was already outnumbered the total population itself (112\%) placing Indonesia ahead of some developed countries like the US, France, Australia, Japan, or South [9]. In terms of the time spent on the Internet, Indonesian 
people consistently ranked way above the average every year. Only Thailand, The Philippines, and Brazil ranked better within the past three years. [9-12]. While these statistics do not necessarily represent quality of technology use, it is clear that Indonesia thrives in terms of technology adoption, particularly in mobile frontline.

\section{Literature Review}

Despite the increasing access to personal computing devices over time at both global and nationals level, there is one big inequality problem in access to, attitude towards, and the use of these devices, also known as digital divide, a term that was first coined in late $20^{\text {th }}$ century and has been well researched topic ever since [16, 19-20]. Some studies confirmed the existence of digital divide between race, age, and gender [3, 7] while some other argue that income or socioeconomic status (SES) is the most important factor of digital divide [1-2]. In terms of university students, major is also considered important factor where students from engineering and technical courses use considerably more technology than students in social sciences majors [14].

On many occasions, several researchers have tried to investigate the relationship between device ownership or use and educational attainment. Some studies suggest the use of mobile device can help improve the quality of education [6, 15]. On the other hand, some other studies also suggest problematic relationship between two of them. In many cases, problematic use of mobile device is mostly about addiction $[5,8,17]$. Either way, the relationship between ICT and education are two-folds, higher participation rate in education, especially in secondary and higher education increases technology utilization, which in turn helps promote better outcomes of education [18].

Finally, while many studies in this topic were done in different parts of the world, there is nothing much learned yet from Indonesian settings. While results from those studies can definitely give a good insight of what might happen in any other places, including Indonesia, there are still some differences, particularly in culture and any other characteristics that may lead to different outcomes. This is why before we can proceed with some sort of conclusion or alternative solutions on how to optimize the use of technology for educational purposes in Indonesia, it will be much better to explore what is actually happening in there in the first place.

\section{$3 \quad$ Methodology}

An online survey was conducted in a private university in Indonesia within the first quarter of 2016. A total of 189 undergraduate students ( 81 females, $43 \%$ and 108 males, $57 \%)$ participated in the study. They came from 7 different majors and ranged from 19 to 27 years of age $(M=21.44, S D=1.59)$. Participants were also categorized based on year in college (26 $1^{\text {st }}$ year, $13.76 \%, 352^{\text {nd }}$ year, $18.52 \%, 603^{\text {rd }}$ year, $31.75 \%$, $394^{\text {th }}$ year, $20.63 \%$, and 29 other in their $5^{\text {th }}$ year or above, $15.34 \%$ ), place of origin (121 Java, 64\% and 68 outside Java, 36\%), self-perceived ICT adoption level representing attitude towards ICT (39 early adopters, 21\%, 129 majorities, 68\%, and 21 laggards, $11 \%$ ), and socioeconomic status (SES) measured by the purchase price of their devices 
(36 high SES, 19\% and 153 middle to low SES, 81\%). Data analysis includes both descriptive and inferential statistics in form of chi-square test and logistic regression models, the latter is used due to the nature of the dependent variables that are in binary form. Due to multicollinearity with year in college, age is omitted in all analyses.

\section{$4 \quad$ Results and Discussion}

Table 1 provides information on device ownership among these students, categorized by gender, major, place of origin, SES, attitude towards ICT, and year in college. Laptop and smartphone have the highest ownership rate, close to $100 \%$ in all groups. Males have higher ownership rate on desktop and smartphone as opposed to females on laptop and tablet. However, the difference is only significant for laptop ( $\mathrm{Pr}<.05$ ) and tablet $(\mathrm{Pr}<.1)$. Students in the high-SES group consistently have higher ownership rate for all four devices, albeit significant only for desktop $(\mathrm{Pr}=.001)$ and tablet $(\mathrm{Pr}<$ .001). Attitude towards ICT has linear relationship with ownership except for laptop that is inverse linear instead. However, the difference is only significant for desktop (Pr $<.1$ ). No difference is found in major, place of origin, and year in college.

The fact that $98 \%$ of these students own at least two devices suggests the need for same analysis with device bundle ownership. Out of 16 possible bundle types, only four major bundles are identified. In decreasing order, they are 1) laptop \& smartphone, 2) desktop, laptop, \& smartphone, 3) all four devices, and 4) laptop, smartphone, \& tablet. Table 2 provides information on these four bundles in addition to those who own only either one of four devices and those who own other types of bundle, each combined as one category. One interesting finding here is that in three major bundles with at least three devices, students with high-SES have higher rate of ownership while the opposite is true for laptop \& smartphone bundle, which is also the most common bundle, owned by $41 \%$ of the students. The difference is highly significant $(\operatorname{Pr}<.001)$ in both the bundle with most devices and the bundle with most owners. Another interesting finding is at the attitude towards ICT where it has different relationship (i.e. linear, inverse linear, u-shaped nonlinear, and inverted u-shaped nonlinear) with the ownership of each one of the four major bundles. This indicates each bundle represents different state of technology adoption level. The most common bundle is associated with the laggards while the bundle with most devices is associated with the early adopters.

In the last analysis, several models were developed to see the effect of all variables of interest to the ownership of both devices and bundles at a multivariate level. The models were significant in the ownership of two devices (i.e. desktop and tablet) and two device bundles (i.e. all four device bundle and laptop \& smartphone bundle) only. Table 3 provides information on these four models. Again, socioeconomic status is proven to be the most important predictor of all. Students with high SES are more likely to own either desktop, tablet, or all four device bundle than students with middle to low SES while the opposite is true for laptop \& smartphone bundle. Gender preference is also confirmed in tablet ownership where females are more likely to own it than males. Finally, attitude towards ICT is also confirmed to be significant predictor of the ownership. Early adopters are more likely to be the owner of this bundle than those in the 
majorities group while the laggards are the least likely to be the owner of all. The effect of all other independent variables (i.e. year in college, major, and place of origin) is not significant in any model, contrary to what previous studies in other countries suggested.

Table 1. Descriptive Statistics on Device Ownership

\begin{tabular}{|c|c|c|c|c|c|c|c|c|}
\hline & \multicolumn{2}{|c|}{ Desktop } & \multicolumn{2}{|c|}{ Laptop } & \multicolumn{2}{|c|}{ Smartphone } & \multicolumn{2}{|c|}{ Tablet } \\
\hline & Freq & (\%) & Freq & (\%) & Freq & $(\%)$ & Freq & (\%) \\
\hline Gender: Male & 53 & 49.07 & 102 & 94.44 & 105 & 97.22 & 22 & 20.37 \\
\hline Female & 36 & 44.44 & 81 & 100.00 & 75 & 92.59 & 26 & 32.10 \\
\hline Major: STEMM & 52 & 45.61 & 109 & 95.31 & 108 & 94.74 & 28 & 24.56 \\
\hline Social Sciences & 37 & 49.33 & 74 & 98.67 & 72 & 96.00 & 20 & 26.67 \\
\hline Place of Origin: Java & 58 & 47.93 & 119 & 98.35 & 115 & 95.04 & 31 & 25.62 \\
\hline Non-Java & 31 & 45.59 & 64 & 94.12 & 65 & 95.59 & 17 & 25.00 \\
\hline Socioeconomic Status: High & 26 & 72.22 & 36 & 100.00 & 36 & 100.00 & 19 & 52.78 \\
\hline Middle to Low & 63 & 41.18 & 147 & 96.08 & 144 & 94.12 & 29 & 18.95 \\
\hline Attitude towards ICT: Early Adopter & 20 & 51.28 & 36 & 92.31 & 38 & 97.44 & 14 & 35.90 \\
\hline Majority & 64 & 49.61 & 126 & 97.67 & 123 & 95.35 & 30 & 23.26 \\
\hline Laggard & 5 & 23.81 & 21 & 100.00 & 19 & 90.48 & 4 & 19.05 \\
\hline Year in College: 1 st year & 12 & 46.15 & 25 & 96.15 & 26 & 100.00 & 9 & 34.62 \\
\hline 2nd year & 18 & 51.43 & 34 & 97.14 & 34 & 97.14 & 9 & 25.71 \\
\hline 3rd year & 28 & 46.67 & 59 & 98.33 & 54 & 90.00 & 17 & 28.33 \\
\hline 4th year & 15 & 38.46 & 38 & 97.44 & 38 & 97.44 & 8 & 20.51 \\
\hline$\geq 5$ th year & 16 & 55.17 & 27 & 93.10 & 28 & 96.55 & 5 & 17.24 \\
\hline All Samples & 89 & 47.09 & 183 & 96.83 & 180 & 95.24 & 48 & 25.40 \\
\hline
\end{tabular}

Table 2. Descriptive Statistics on Device Bundle Ownership

\begin{tabular}{|c|c|c|c|c|c|c|c|c|c|c|c|c|}
\hline & \multicolumn{2}{|c|}{$\begin{array}{l}\text { All Four } \\
\text { Devices }\end{array}$} & \multicolumn{2}{|c|}{$\begin{array}{c}\text { Desktop, } \\
\text { Laptop \& } \\
\text { Smartphone }\end{array}$} & \multicolumn{2}{|c|}{$\begin{array}{c}\text { Laptop, } \\
\text { Smartphone } \\
\text { \& Tablet }\end{array}$} & \multicolumn{2}{|c|}{$\begin{array}{l}\text { Laptop \& } \\
\text { Smartphone }\end{array}$} & \multicolumn{2}{|c|}{$\begin{array}{l}\text { Either One } \\
\text { Only }\end{array}$} & \multicolumn{2}{|c|}{$\begin{array}{l}\text { Other } \\
\text { Bundles }\end{array}$} \\
\hline & Freq & (\%) & Freq & (\%) & Freq & (\%) & Freq & $(\%)$ & Freq & (\%) & Freq & (\%) \\
\hline Gender: Male & 12 & 11.11 & 35 & 32.41 & 9 & 8.33 & 43 & 39.81 & 3 & 2.78 & 6 & 5.56 \\
\hline Female & 16 & 19.75 & 19 & 23.46 & 5 & 6.17 & 35 & 43.21 & 1 & 1.23 & 5 & 6.18 \\
\hline Major: STEMM & 13 & 11.40 & 33 & 28.95 & 10 & 8.77 & 47 & 41.23 & 2 & 1.75 & 9 & 7.90 \\
\hline Social Sciences & 15 & 20.00 & 21 & 28.00 & 4 & 5.33 & 31 & 41.33 & 2 & 2.67 & 2 & 2.67 \\
\hline Place of Origin: Java & 19 & 15.70 & 37 & 30.58 & 9 & 7.44 & 48 & 39.67 & 4 & 3.31 & 4 & 3.31 \\
\hline Non-Java & 9 & 13.24 & 17 & 25.00 & 5 & 7.35 & 30 & 44.12 & 0 & 0.00 & 7 & 10.29 \\
\hline SES: High & 14 & 38.89 & 12 & 33.33 & 5 & 13.89 & 5 & 13.89 & 0 & 0.00 & 0 & 0.00 \\
\hline Middle to Low & 14 & 9.15 & 42 & 27.45 & 9 & 5.88 & 73 & 47.71 & 4 & 2.61 & 11 & 7.20 \\
\hline Attitude: Early Adopter & 9 & 23.08 & 8 & 20.51 & 4 & 10.26 & 14 & 35.90 & 1 & 2.56 & 3 & 7.69 \\
\hline Majority & 18 & 13.95 & 42 & 32.56 & 7 & 5.43 & 53 & 41.09 & 1 & 0.78 & 8 & 6.19 \\
\hline Laggard & 1 & 4.76 & 4 & 19.05 & 3 & 14.29 & 11 & 52.38 & 2 & 9.52 & 0 & 0.00 \\
\hline Year in College: 1 st year & 5 & 19.23 & 6 & 23.08 & 4 & 15.38 & 10 & 38.46 & 0 & 0.00 & 1 & 3.85 \\
\hline 2nd year & 7 & 20.00 & 11 & 31.43 & 1 & 2.86 & 14 & 40.00 & 1 & 2.86 & 1 & 2.86 \\
\hline 3rd year & 8 & 13.33 & 18 & 30.00 & 5 & 8.33 & 22 & 36.67 & 2 & 3.33 & 5 & 8.35 \\
\hline 4th year & 5 & 12.82 & 9 & 23.08 & 3 & 7.69 & 20 & 51.28 & 1 & 2.56 & 1 & 2.56 \\
\hline$\geq 5$ th year & 3 & 10.34 & 10 & 34.48 & 1 & 3.45 & 12 & 41.38 & 0 & 0.00 & 3 & 10.35 \\
\hline All Samples & 28 & 14.81 & 54 & 28.57 & 14 & 7.41 & 78 & 41.27 & 4 & 2.12 & 11 & 5.82 \\
\hline
\end{tabular}


Table 3. Logistic Regression Estimates of Device \& Device Bundle Ownership

\begin{tabular}{|c|c|c|c|c|}
\hline & \multicolumn{2}{|c|}{ Device Ownership } & \multicolumn{2}{|c|}{ Device Bundle Ownership } \\
\hline & Desktop & Tablet & All Four Devices & Laptop \& Smartphone \\
\hline $\begin{array}{l}\text { Gender } \\
\text { (Male) }\end{array}$ & $\begin{array}{l}1.307 \\
(.444)\end{array}$ & $\begin{array}{l}.476^{*} \\
(.190)\end{array}$ & $\begin{array}{l}.513 \\
(.254)\end{array}$ & $\begin{array}{l}.828 \\
(.284)\end{array}$ \\
\hline Attitude Towards ICT & $\begin{array}{l}.700 \\
(.201)\end{array}$ & $\begin{array}{l}.621 \\
(.213)\end{array}$ & $\begin{array}{l}.440^{*} \\
(.196)\end{array}$ & $\begin{array}{l}1.175 \\
(.341)\end{array}$ \\
\hline $\begin{array}{l}\text { Socioeconomic Status } \\
\text { (High Income) }\end{array}$ & $\begin{array}{c}3.737 * * * \\
(1.569)\end{array}$ & $\begin{array}{c}4.299 * * * \\
(1.760)\end{array}$ & $\begin{array}{c}5.332^{* * *} \\
(2.476)\end{array}$ & $\begin{array}{l}.171^{* * *} \\
(.089)\end{array}$ \\
\hline Year in College & $\begin{array}{l}1.114 \\
(.121)\end{array}$ & $\begin{array}{l}.898 \\
(.120)\end{array}$ & $\begin{array}{l}.985 \\
(.161)\end{array}$ & $\begin{array}{l}1.005 \\
(.110)\end{array}$ \\
\hline $\begin{array}{l}\text { Major } \\
\text { (STEMM) }\end{array}$ & $\begin{array}{l}.752 \\
(.260)\end{array}$ & $\begin{array}{l}1.351 \\
(.546)\end{array}$ & $\begin{array}{l}.615 \\
(.302)\end{array}$ & $\begin{array}{l}.946 \\
(.332)\end{array}$ \\
\hline $\begin{array}{l}\text { Place of Origin } \\
\text { (Java) }\end{array}$ & $\begin{array}{l}1.152 \\
(.371)\end{array}$ & $\begin{array}{l}1.223 \\
(.463)\end{array}$ & $\begin{array}{l}1.506 \\
(.720)\end{array}$ & $\begin{array}{l}.782 \\
(.255)\end{array}$ \\
\hline Constant & $\begin{array}{l}.912 \\
(.674)\end{array}$ & $\begin{array}{l}.894 \\
(.785)\end{array}$ & $\begin{array}{l}.699 \\
(.781)\end{array}$ & $\begin{array}{l}.893 \\
(.673)\end{array}$ \\
\hline $\begin{array}{l}\text { Model } \chi^{2} \\
\text { Pseudo } R^{2} \text { (McFadden) } \\
\text { Df } \\
\text { Observation }\end{array}$ & $\begin{array}{c}15.32 * * \\
.059 \\
6 \\
189\end{array}$ & $\begin{array}{c}21.64 * * * \\
.101 \\
6 \\
189\end{array}$ & $\begin{array}{c}23.63 * * * \\
.149 \\
6 \\
189\end{array}$ & $\begin{array}{c}17.07 * * * \\
.067 \\
6 \\
189\end{array}$ \\
\hline
\end{tabular}

\section{$5 \quad$ Conclusion and Future Works}

In this paper, differences in device ownership are identified where students with high-SES are about four times more likely to own either desktop or tablet than those with middle to low SES while females are more likely to own tablet than males. Contrary to previous studies in other countries, the difference in major was not found in this study, STEMM students are not more likely to own devices or bundles than social sciences students. The same is true for location where students from both Java and outside Java island, each representing more and less developed area, don't differ in the likelihood of ownership. There is also no significant difference found in terms of age or year in college, presumably due to the fact that all of these students are basically the same millennial generation born in 1990s. The age factor would have had stronger role if the comparison was made with older (e.g. postgraduate) students born in 1980s and later or with younger (e.g. secondary school) students born in 2000s and later. Despite its merit in identifying differences and important factor of device ownership, this study is still in preliminary phase. The long-term goal is to investigate the relationship between device ownership/use and educational attainment, especially with the fact that same online survey used in this study contains more data related to students' activities with mobile device, their online \& mobile learning activities and their attitude toward them. 


\section{References}

1. Calvert, S. L., Rideout, V. J., Woolard, J. L., Barr, R. F., \& Strouse, G. A. (2005). Age, ethnicity, and socioeconomic patterns in early computer use a national survey. American Behavioral Scientist, 48(5), 590-607.

2. Chinn, M. D., \& Fairlie, R. W. (2006). The determinants of the global digital divide: a crosscountry analysis of computer and internet penetration. Oxford Economic Papers.

3. Colley, A., \& Comber, C. (2003). Age and gender differences in computer use and attitudes among secondary school students: what has changed? Educational Research, 45(2), 155-165.

4. Goerke, V., \& Oliver, B. (2007). Australian undergraduates' use and ownership of emerging technologies: Implications and opportunities for creating engaging learning experiences for the Net Generation. Australasian Journal of Educational Technology, 23(2), 171.

5. Hong, F. Y., Chiu, S. I., \& Huang, D. H. (2012). A model of the relationship between psychological characteristics, mobile phone addiction and use of mobile phones by Taiwanese university female students. Computers in Human Behavior, 28(6), 2152-2159.

6. Hwang, G. J., Wu, P. H., \& Ke, H. R. (2011). An interactive concept map approach to supporting mobile learning activities for natural science courses. Computers \& Education, 57(4).

7. Jackson, L. A., Zhao, Y., Kolenic III, A., Fitzgerald, H. E., Harold, R., \& Von Eye, A. (2008). Race, gender, and information technology use: the new digital divide. CyberPsychology \& Behavior, 11(4), 437-442.

8. Kamibeppu, K., \& Sugiura, H. (2005). Impact of the mobile phone on junior high-school students' friendships in the Tokyo metropolitan area. Cyberpsychology \& Behavior, 8(2).

9. Kemp, S. (2014). Social, Digital \& Mobile Worldwide in 2014. Retrieved December 7, 2015, from http://wearesocial.com/uk/special-reports/social-digital-mobile-worldwide-2014

10. Kemp, S. (2015). Social, Digital \& Mobile Worldwide in 2015. Retrieved December 7, 2015, from http://wearesocial.com/uk/special-reports/social-digital-mobile-worldwide-2015

11. Kemp, S. (2016). Digital in 2016. Retrieved February 9, 2017, from http://wearesocial.com/uk/special-reports/digital-in-2016

12. Kemp, S. (2017). Digital in 2017: Global Review. Retrieved February 9, 2017, from http://wearesocial.com/blog/2017/01/digital-in-2017-global-overview

13. Kobus, M. B., Rietveld, P., \& Van Ommeren, J. N. (2013). Ownership versus on-campus use of mobile IT devices by university students. Computers \& Education, 68, 29-41.

14. Margaryan, A., Littlejohn, A., \& Vojt, G. (2011). Are digital natives a myth or reality? University students' use of digital technologies. Computers \& Education, 56(2), 429-440.

15. Martin, F., \& Ertzberger, J. (2013). Here and now mobile learning: An experimental study on the use of mobile technology. Computers \& Education, 68, 76-85.

16. Norris, P. (2001). Digital divide: Civic engagement, information poverty, and the Internet worldwide. Cambridge University Press.

17. Ozkan, M., \& Solmaz, B. (2015). Mobile Addiction of Generation Z and its Effects on their Social Lifes:(An Application among University Students in the 18-23 Age Group). ProcediaSocial and Behavioral Sciences, 205, 92-98.

18. Pratama, A. R. (2016). Cross-country Analysis of ICT and Education Indicators: An Exploratory Study. International Conference on Information Technology \& Digital Applications.

19. Pratama, A.R. \& Al-Shaikh, M. (2012). Relation and Growth of Internet Penetration Rate with Human Development Level from 2000 to 2010. Communications of the IBIMA, 2012.

20. Sidorenko, A., \& Findlay, C. (2001). The digital divide in East Asia. Asian-Pacific Economic Literature, 15(2), 18-30. 